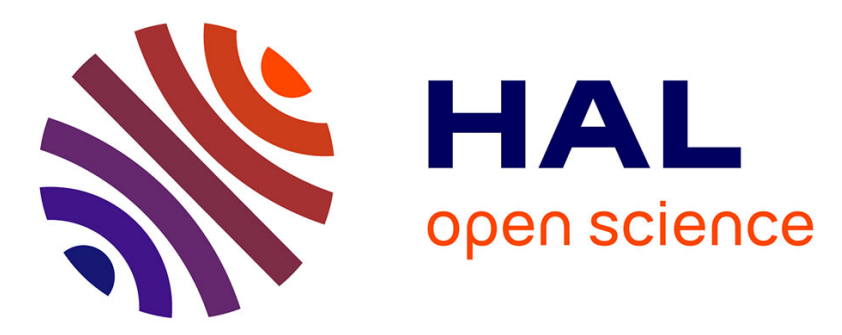

\title{
Visible optical spectra of [MATH]-irradiated uranium - doped ZBLAN fibres
}

Sylvain Magne, G. Boisdé, G. Monnom, Y. Ouerdane, M. Druetta, J. Goure, G. Mazé

\section{To cite this version:}

Sylvain Magne, G. Boisdé, G. Monnom, Y. Ouerdane, M. Druetta, et al.. Visible optical spectra of [MATH]-irradiated uranium - doped ZBLAN fibres. Journal de Physique IV Proceedings, 1994, 04 (C4), pp.C4-451-C4-454. 10.1051/jp4:19944108 . jpa-00252557

\section{HAL Id: jpa-00252557 https://hal.science/jpa-00252557}

Submitted on 1 Jan 1994

HAL is a multi-disciplinary open access archive for the deposit and dissemination of scientific research documents, whether they are published or not. The documents may come from teaching and research institutions in France or abroad, or from public or private research centers.
L'archive ouverte pluridisciplinaire HAL, est destinée au dépôt et à la diffusion de documents scientifiques de niveau recherche, publiés ou non, émanant des établissements d'enseignement et de recherche français ou étrangers, des laboratoires publics ou privés. 


\title{
Visible optical spectra of $\gamma$-irradiated uranium - doped ZBLAN fibres
}

\author{
S. MAGNE*, G. BOISDÉ*, G. MONNOM ${ }^{* *}$, Y. OUERDANE, M. DRUETTA, J.P. GOURE and \\ G. MAZÉ *** \\ Laboratoire TSI, URA 842 du CNRS, 42023 Saint-Etienne cedex 2, France \\ * Commissariat à l'Energie Atomique, LETI-DEIN, CEN Saclay, 91191 Gif-sur-Yvette cedex, France \\ ** Laboratoire de Physique de la Matière Condensée, URA 190 du CNRS, Parc Valrose, 06108 Nice cedex, \\ France \\ ${ }^{* * *}$ Le Verre Fluoré SA, ZI du Champ Martin, 35770 Vern-sur-Seiche, France
}

\begin{abstract}
Actinides, particularly uranium, are again of interest because these elements provide a broad spectroscopic tunability and open a new field of fibre laser applications.

The uranium ion possesses many oxidation states, the most stable being $U^{4+}$ and $U^{6+} . U^{3+}$ is an unusual oxidation state in fluorides. $U^{3+}$ is of interest because it can provide an efficient laser emission of between 2 and $2.7 \mu \mathrm{m}$. We report visible absorption and fluorescence spectra of pure and $\gamma$-irradiated uranium - doped ZBLAN fibres. We show that yirradiation leads to a high reduction of $U^{4+}$ into $U^{3+}$, which is stable over a few years.

Strong absorption bands of $U^{4+}$ and $U^{3+}$, centered at $650 \mathrm{~nm}$ and $860 \mathrm{~nm}$ respectively, enable us to estimate the change of the uranium oxidation state.
\end{abstract}

\section{I - INTRODUCTION}

Lanthanides and actinides can exist in many oxidation states depending upon oxydizing or reducting processing conditions. However, only actinides have many stable oxidation states (the trivalent form is the most stable state for all lanthanide ions). The field of application of lasers in general, and fibre lasers, in particular, can be broadened by changing the oxidation states of active ions.

These oxidation states are inherently dependent on the fabrication process which imposes the oxydoreduction conditions. In contrast, the irradiation technique used in this experiment, enable us to change the states of oxidation after processing.

Among actinides, uranium has been the most widely studied since 1960 [1], when its trivalent form was substituted for calcium in a $\mathrm{CaF}_{2}$ cristalline matrix.

Actinides are of interest, because they are subject to a higher vibronic coupling than lanthanides leading to broader linewidths and so broader tunabilities. Moreover, the tunabilities are even larger in glasses due to the inhomogeneous broadening. When incorporated in fibre form, the confinement of the optical energy enables increasing the optical gain [2]. Therefore, CW laser operation is possible in fibre form despite broad linewidths, though it is more harder to achieve in bulk form. The uranium ion possesses many oxidation states [3], the most stable being $\mathrm{U}^{4+}$ and $\mathrm{U}^{6+} . \mathrm{U}^{3+}$ is an unusual oxidation state in fluoride but is interesting because it can provide an efficient laser emission of between 2 and $2.7 \mu \mathrm{m}$, as previously described [1].

\section{II - EXPERIMENT}

We recorded absorption and luminescence visible optical spectra of both pure and $\gamma$-irradiated uranium-doped ZBLAN fibres. 
Irradiations were performed on one fibre using a $\mathrm{Co}^{60}$ source. The dose rate was $2.10^{4} \mathrm{Rad} /$ hour and the irradiation time was 300 hours. The concentration of uranium was $1000 \mathrm{ppm}$ The absorption spectra (fig. 1) were recorded three years after irradiation on fibre whereas the spectra (fig. 2) were recorded, on thepreform, immediately after irradiation.

Absorption spectra

The absorption coefficient is determined by the cut-back method and the visible absorption spectra of both fibres are shown in fig. 1 .

Three main absorption bands are specific for each valence state : around $480 \mathrm{~nm}$ (mean), around $625 \mathrm{~nm}$ to $650 \mathrm{~nm}$ (very strong) and around $870 \mathrm{~nm}$ (weak) for $\mathrm{U}^{4+}$, whereas $\mathrm{U}^{3+}$ possesses three absorption bands around $600 \mathrm{~nm}$ (mean), $715 \mathrm{~nm}$ (weak) and $860 \mathrm{~nm}$ (very strong). The absorption band centered at $860 \mathrm{~nm}$ enables us to distinguish the two oxidation states. These observations are in agreement with the results obtained by Clare et al.[3].in fluorozirconate and fluoroaluminate glasses. Luminescence spectra

The luminescence spectra were recorded with a Czerny-Turner spectrometer equipped with a photomultiplier. The fibres were excited using an Argon-ion laser emitting either at $514 \mathrm{~nm}$ or at 488 $\mathrm{nm}$. The luminescence spectra of each fibre was compared for two excitation wavelengths ( $488 \mathrm{~nm}$ and $514 \mathrm{~nm}$ ) (fig. 3). Some bands are observed that are not present in the absorption spectrum showing relaxation to other levels than the fondamental one.

A transition around 680 to $700 \mathrm{~nm}$ is clearly observed, only for the irradiated fiber.

The identification of the oxidation states is difficult because the energy-level diagrams are complex and dependent on the host matrix. In comparison to earlier spectra [4], we show that the $\gamma$-irradiation leads to a high reduction of $\mathrm{U}^{4+}$ into $\mathrm{U}^{3+}$ in ZBLAN fluoride glass.

This experiment confirms the validity of the irradiation technique which has proven useful with other matrices [5].

Further analysis requires performing I.R. fluorescence measurements and Electron Spin Resonance (ESR) experiments in order to selectively determine the proportion of $\mathrm{U}^{3+}$ (odd valence state) in respect to $\mathrm{U}^{4+}$ (even valence state) as no ESR signal arises from $\mathrm{U}^{4+}$.

\section{REFERENCES}

[1] P.P. Sorokin and M.J. Stevenson.

Phys. Rev. Lett. 5, 557, (1960)

[2] S. Magne

PhD Thesis, Saint-Etienne, France (1993)

[3] Alexis G. Clare, John M. Parker, D. Furniss, E.A. Harris and T.M. Searle

J. Phys. Condens. Matter, 1, p 8753 (1989)

[4] L.M. Toth

J. Phys. Chem., 75 , 5, 631 (1971)

[5] S. Hubert, E. Simoni, M. Louis, W.P. Zhang and J.Y. Gesland

ICL'93 Th 5-81, University of Connecticut, Storrs, CT, USA (1993) 


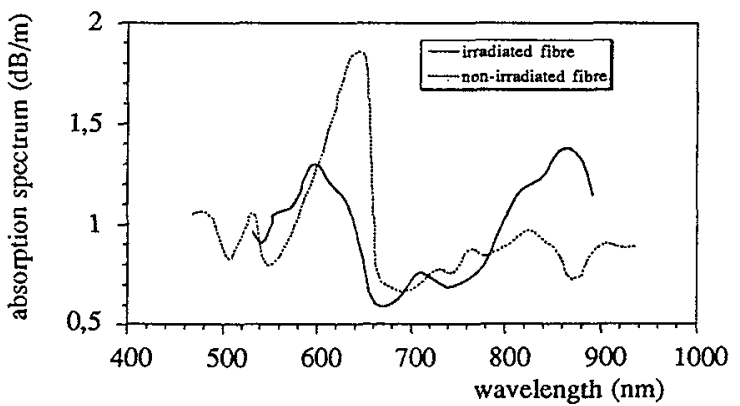

Fig 1: Absorption spectra of $\gamma$-irradiated and non-irradiated uranium-doped ZBLAN fibres. (The spectrum of the non-irradiated fibre is in relative units).
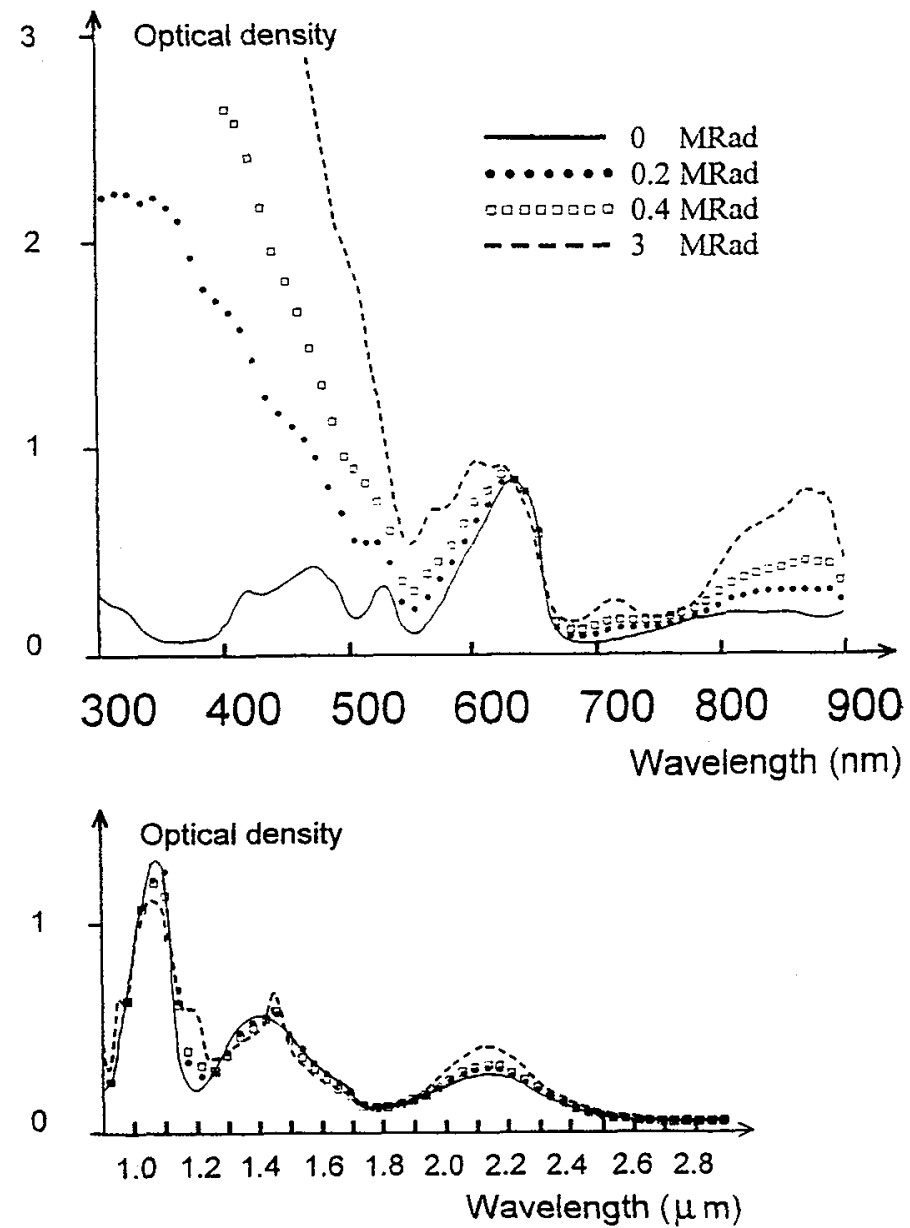

Fig 2: Evolution of the absorption spectrum of the uranium-doped ZBLAN fibre preform with the $\gamma$-irradiation dose ( the dose rate was $210^{4} \mathrm{Rad} / \mathrm{hour}$ ). 

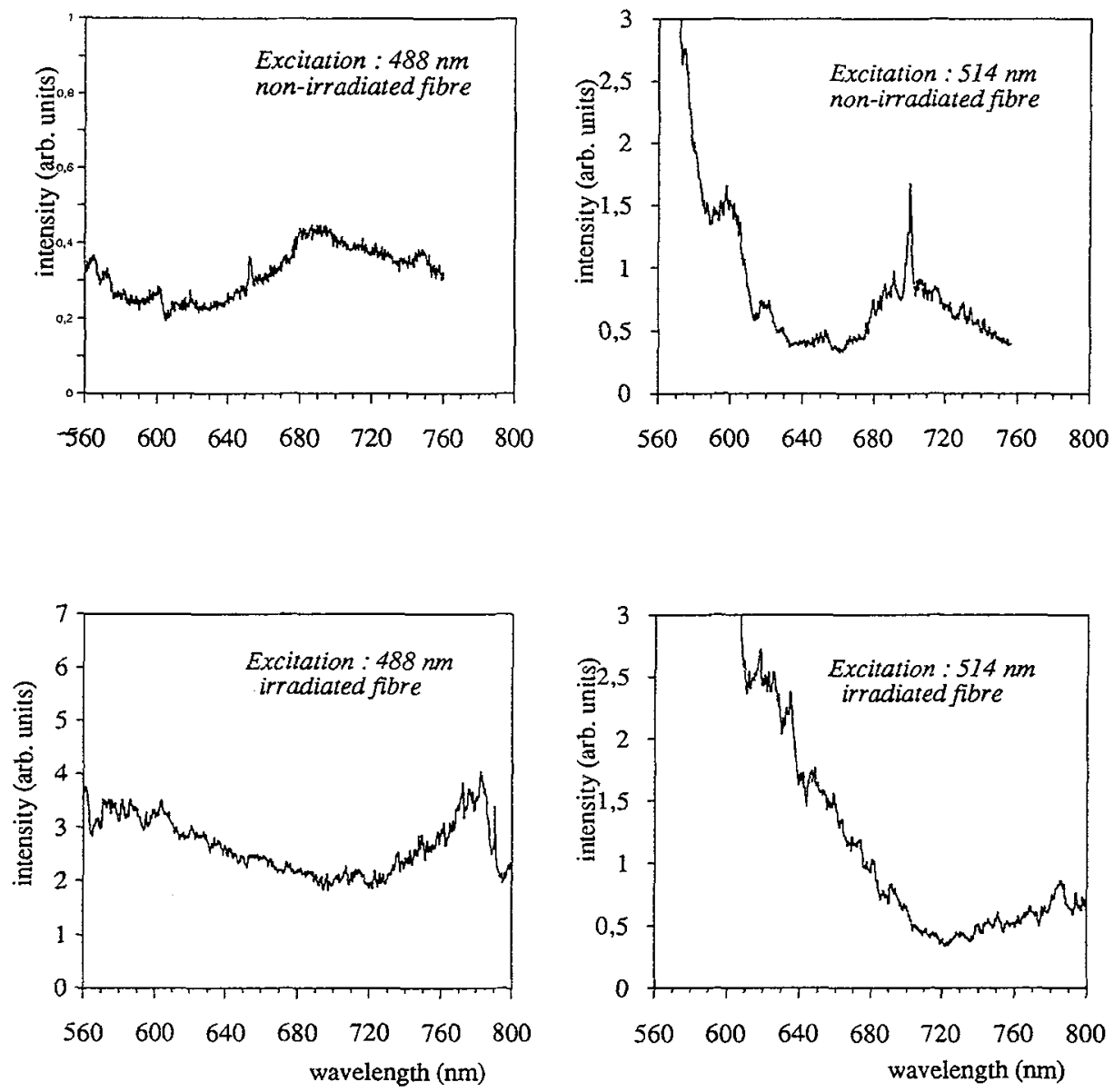

Fig 3: Luminescence spectra of both irradiated and non-irradiated uranium-doped ZBLAN fibres under two different excitation wavelengths: $488 \mathrm{~nm}$ and $514 \mathrm{~nm}$. 